\title{
PENGARUH PROGRAM PELATIHAN DAN MOTIVASI KERJA TERHADAP KINERJA KARYAWAN PT. TD AUTOMOTIVE COMPRESSOR INDONESIA
}

\author{
Maulia Eka Riani*)1, M. Syamsul Maarif"), dan Joko Affandi**) \\ *) Sekolah Bisnis, Institut Pertanian Bogor \\ Jl. Raya Pajajaran, Bogor 16151 \\ **) PPM Manajemen \\ Jl. Menteng Raya 9, Jakarta 10340
}

\begin{abstract}
PT. TD Automotive Compressor Indonesia (PT TACI) needs to analyze how much training and motivation factors affect its employee performance. The purposes of this study were to analyze the influence of training on the employee work motivation, analyze the influence of training on the employee performance, and analyze the influence of motivation on the performance of employees of PT. TACI. This research used SEM (Structural Equation Modeling). The results showed that training has a significant and positive influence on the employee work motivation. Furthermore, training has a significant and positive impact on employee performance. Conversely, work motivation has a significant and positive influence on the employee performance.
\end{abstract}

Keywords: leader, training, motivation, employee performance, SEM

\begin{abstract}
ABSTRAK
PT. TD Automotive Compressor Indonesia (PT. TACI) perlu dilakukan untuk dapat menganalisis seberapa besar faktor pelatihan dan motivasi memengaruhi kinerja karyawan. Tujuan penelitian ini adalah menganalisis pengaruh pelatihan terhadap motivasi kerja karyawan PT. TACI, menganalisis pengaruh pelatihan terhadap kinerja karyawan PT. TACI, dan menganalisis pengaruh motivasi terhadap kinerja karyawan PT. TACI. Penelitian ini menggunakan SEM (Structural Equation Modelling). Hasil penelitian menunjukkan bahwa pelatihan berpengaruh significant dan positif terhadap motivasi kerja karyawan. Selanjutnya, pelatihan berpengaruh significant dan positif terhadap kinerja karyawan. Sebaliknya, motivasi kerja berpengaruh significant dan positif terhadap kinerja karyawan.
\end{abstract}

Keywords: leader, training, motivation, employee performance, SEM

\footnotetext{
${ }^{1}$ Alamat Korespondensi:

Email: mauliaekariani@gmail.com
}

\section{PENDAHULUAN}

Industri otomotif Indonesia berperan penting dalam sektor manufaktur di negara ini, karena banyak perusahaan mobil yang terkenal di dunia mendirikan pabriknya dan meningkatkan kapasitas produksinya di Indonesia. Jumlah produksi mobil pada tahun 2015 mencapai 1.098.780 unit. Perusahaan manufaktur mobil dari Jepang tetap dominan dalam industri manufaktur mobil Indonesia. Lebih dari setengah jumlah total mobil yang dijual secara domestik adalah mobil yang diproduksi oleh perusahaan manufaktur dari Jepang tersebut (Gaikindo, 2015). Berdirinya industri mobil tersebut ikut mendorong bermunculannya industri pendukung untuk memproduksi komponen, yang akhirnya akan membuka kesempatan lapangan pekerjaan. Tenaga kerja yang dibutuhkan untuk memenuhi lapangan pekerjaan tersebut tentu saja adalah Sumber Daya Manusia (SDM) yang kompeten memiliki kompetensi tertentu yang dibutuhkan untuk menunjang keberhasilan pelaksanaan pekerjaannya.

PT. TD Automotive Compressor Indonesia (PT. TACI) adalah perusahaan Penanaman Modal Asing (PMA) yang sahamnya dimiliki oleh Toyota Industries Corporation Jepang 50,1\%, Astra Otoparts 25,7\%, Denso International Asia $20 \%$ dan Toyota Tsusho Indonesia $4,2 \%$. 
Perusahaan ini adalah salah satu perusahaan pembuat komponen kendaraan bermotor yang baru berusia lima tahun di Indonesia dengan jumlah karyawan sebanyak 1.878 orang. Komposisi jumlah karyawannya adalah operator 1.599 orang, leader 104 orang, supervisor 98 orang dan manajer 77 orang. Operator adalah karyawan yang secara langsung melakukan kegiatan produksi dan memiliki keterampilan terhadap proses tertentu. Operator melakukan pekerjaan atas instruksi leader. Seorang leader memimpin 15-20 operator dalam unit kerjanya, sedangkan seorang supervisor memimpin satu atau dua unit kerja. Manajer memimpin skala yang lebih besar, yaitu departemen dalam perusahaan. Tantangan untuk menghadapi perkembangan dunia industri mengakibatkan adanya tuntutan terhadap kinerja SDM yang tinggi. Terdapat tiga faktor utama yang memengaruhi individu dalam bekerja dan meningkatkan kinerjanya. Faktor - faktor tersebut adalah kemampuan individu untuk melakukan pekerjaan, tingkat usaha dan dukungan organisasi. (Mathis dan Jackson, 2003). Kinerja individu akan meningkat ketika kemampuan individu meningkat, ada dorongan atau usaha dari individu dan adanya dukungan dari organisasinya.

Hasil wawancara tahap awal, perusahaan menghadapi permasalahan yaitu ketidakpercayaan diri seorang leader dalam mengajarkan anggotanya sehingga yang terjadi adalah penyimpangan seperti kecelakaan kerja yang tidak menyebabkan kehilangan hari kerja sebanyak tiga kali dan setelah di analisa kecelakaan tersebut terjadi karena prilaku tidak aman, produk tidak sesuai standar 2\% dari total produksi selama juli - desember 2015 dan jumlah yang di produksi tidak sesuai dengan yang direncanakan. Seorang leader memiliki tugas dan tanggung jawab khusus untuk bisa melatih dan mengajarkan anggotanya. Oleh karena itu, perusahaan memberikan pelatihan kepada karyawan tingkat leader mengenai langkah-langkah dasar untuk mengajar secara efektif dan efisien karena pada dasarnya leader harus mampu mangajarkan anggotanya agar dapat melakukan pekerjaannya dengan baik.

Program pelatihan untuk leader PT. TACI ini adalah TICO Job Instruction Training (TI-JI), pelatihan ini dilaksanakan selama delapan jam. Melalui pelatihan ini perusahaan berharap agar dapat meningkatkan motivasi kerja. Tabassi et al. (2012) menyatakan bahwa pelatihan berpengaruh signifikan terhadap motivasi. Motivasi kerja merupakan keinginan yang menggerakkan diri karyawan untuk bekerja dengan baik dan mencapai tujuan tertentu. Motivasi merupakan bagian yang sangat penting dari kinerja karyawan (Nawab et al. 2011). Kinerja adalah hasil kerja yang dicapai oleh seseorang karyawan dalam melaksanakan tugasnya sesuai dengan tanggung jawab yang diberikan (Mangkunegara, 2005)

Berdasarkan latar belakang tersebut, studi kinerja karyawan di PT. TACI perlu dilakukan untuk dapat menganalisis seberapa besar faktor pelatihan dan motivasi memengaruhi kinerja karyawan. Penelitian ini dilakukan terhadap karyawan yang memiliki jabatan sebagai leader dan telah mendapatkan pelatihan TI-JI (TICO Job Instruction).

PT. TD Automotive Compressor Indonesia (PT. TACI) telah membuat program pelatihan kepada karyawan tingkat leader mengenai langkah - langkah dasar untuk mengajar secara efektif dan efisien karena pada dasarnya leader harus mampu mangajarkan anggotanya agar dapat melakukan pekerjaannya dengan baik. Pelatihan dan motivasi kerja diharapkan akan sangat membantu dalam meningkatkan kemampuan kerja yang terampil dan berkualitas, sehingga karyawan dapat bekerja secara efektif dan efisien yang diharapkan dapat meningkatkan kinerja karyawan.

Tujuan penelitian ini adalah menganalisis pengaruh pelatihan terhadap motivasi kerja karyawan PT. TACI, menganalisis pengaruh pelatihan terhadap kinerja karyawan PT. TACI, dan menganalisis pengaruh motivasi terhadap kinerja karyawan PT. TACI. Penelitian saat ini difokuskan pada karyawan dengan jabatan leader yang telah mendapatkan pelatihan.

\section{METODE PENELITIAN}

Penelitian ini adalah penelitian deskriptif dengan menggunakan survei yang bertujuan memperoleh gambaran suatu kondisi atau keadaan tentang pengaruh program pelatihan dan motivasi kerja terhadap kinerja karyawan PT. TACI. Penelitian dengan teknik survei didefinisikan sebagai penelitian yang dilakukan terhadap populasi dan sampel dari variabel yang digunakan diteliti melalui pengumpulan data secara kuantitatif menggunakan kuesioner. Kemudian data yang terkumpul akan diolah dan dianalisa melalui teknik statistik untuk menganalisis secara umum tentang pengaruh pelatihan dan motivasi terhadap kinerja karyawan. 
Penelitian dilakukan di PT. TACI Kawasan Industri MM2100 Cibitung-Bekasi. Pengumpulan data dilakukan selama dua bulan, yaitu pada Juli - Agustus 2016, untuk selanjutnya dilakukan analisis terhadap data yang diperoleh. Data yang digunakan dalam penelitian ini adalah data primer dan data sekunder yang berkaitan dengan topik penelitian. Data primer diperoleh dari pengisian kuesioner oleh seluruh leader yang telah mendapatkan pelatihan TI-JI (TICO Job Instruction) yaitu sebanyak 104 orang. Sedangkan data sekunder diperoleh melalui berbagai sumber studi pustaka, seperti buku, jurnal, dan laporan yang dikeluarkan dari instansi atau lembaga, serta beberapa dari literatur internet yang terkait dengan penelitian ini.

Penelitian ini menggunakan SEM (Structural Equation Modelling), karena SEM merupakan analisis yang tepat digunakan untuk analisis multivariat dalam penelitian social, selain itu karena peneliti harus menggunakan variabel laten (variabel yang tidak dapat diukur secara langsung) yaitu pelatihan, motivasi dan kinerja sehingga peneliti harus menggunakan beberapa indikator atau pertanyaan kuesioner. Selain itu SEM mampu menguji penelitian yang kompleks dan banyak variabel secara simultan. SEM dapat menyelesaikan analisis dengan satu kali estimasi SEM dapat melakukan analisis faktor, regresi dan jalur sekaligus. Kerangka pemikiran penelitian selengkapnya pada Gambar 1.

Untuk mengetahui pengaruh pelatihan dan motivasi kerja terhadap kinerja maka hipotesis yang dirumuskan adalah sebagai berikut :

H1 : Pelatihan berpengaruh terhadap motivasi kerja melalui peningkatan peningkatan pelatihan dapat meningkatkan motivasi kerja

H2 : Pelatihan berpengaruh terhadap kinerja Melalui peningkatan pelatihan dapat meningkatkan kinerja

H3 : Motivasi kerja berpengaruh terhadap kinerja melalui peningkatan motivasi kerja dapat meningkatkan kinerja

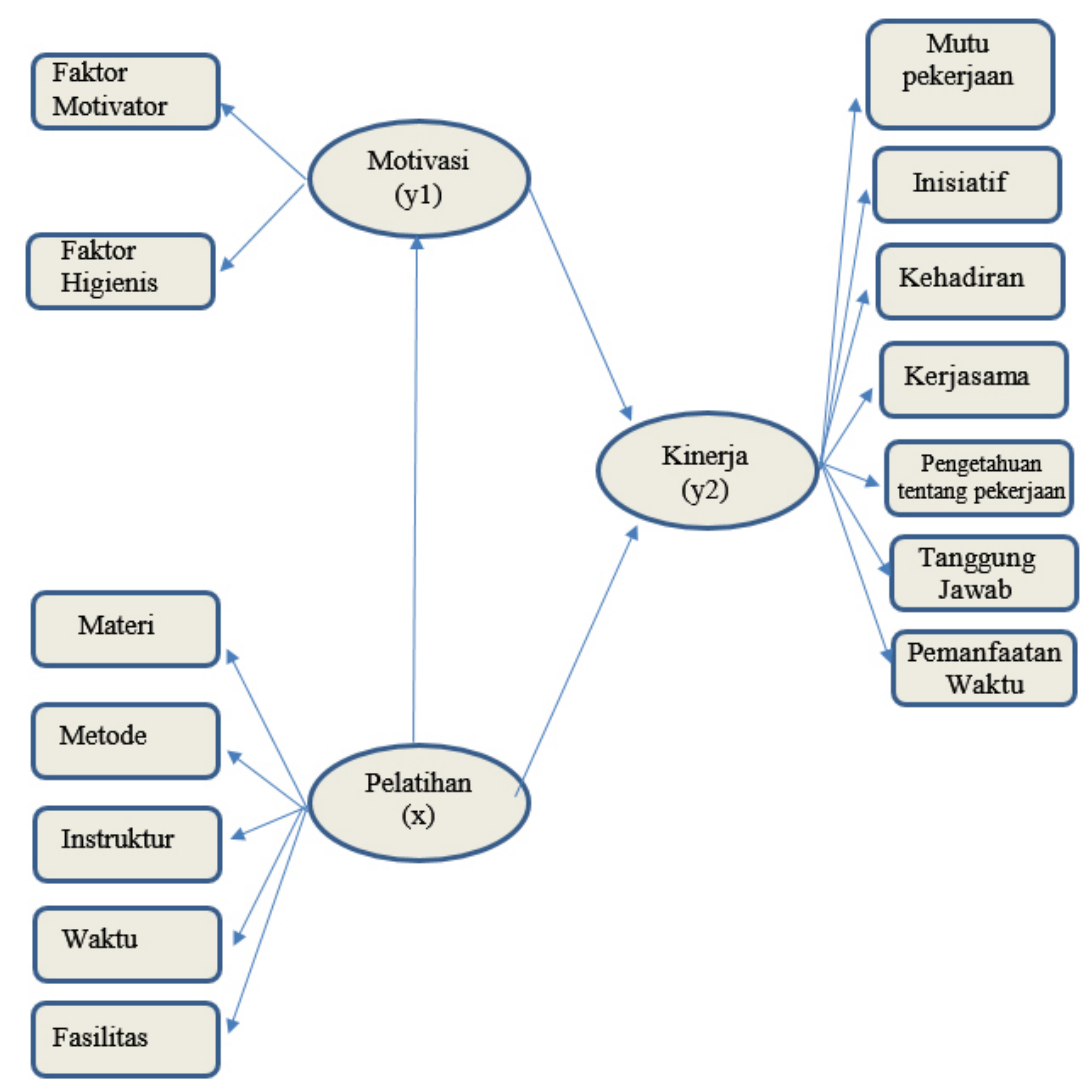

Gambar 1. Kerangka pemikiran penelitian 


\section{HASIL}

\section{Karakteristik Responden}

Gambaran umum responden menjelaskan tentang karakteristik responden dalam penelitian ini. Karakteristik responden meliputi jenis kelamin, usia, status perkawinan, masa kerja dan pendidikan terakhir. Penjelasan masing-masing karakteristik responden selengkapnya pada Tabel 1.

\section{Deskriptif Sebaran Jawaban Pertanyaan Variabel}

Jawaban responden tampil dari kuesioner yang diberikan berupa jumlah atau frekuensi jawaban, total dan modus. Pernyataan yang memiliki skor total tertinggi dari variebel materi pelatihan adalah materi yang disampaikan membantu menyelesaikan pekerjaan. Pernyataan tersebut memiliki total skor sebesar 417 dan modus setuju. Pernyataan yang memiliki skor terendah sebesar 390, yaitu manfaat materi yang disampaikan dalam pekerjaan sehari-hari. Artinya, materi pelatihan yang diberikan kepada karyawan memberikan manfaat yang berarti untuk dapat membantu menyelesaikan pekerjaan para karyawan.

Pernyataan yang memiliki skor total tertinggi variable metode pelatihan adalah kesesuaian metode pelatihan yang diterapkan oleh pengajar dengan keinginan peserta pelatihan. Pernyataan tersebut memiliki total skor sebesar 420 dan modus setuju. Pernyataan yang memiliki skor terendah sebesar 352, yaitu Metode pelatihan sudah cukup memadai sehngga tidak perlu ada perubahan metode. Artinya, para karyawan merasa apa yang diharapkan terhadap pelatihan sudah sesuai dengan yang diberikan dalam pelatihan.

Pernyataan yang memiliki skor total tertinggi dari variabel instruktur adalah kemampuan instruktur alam menanggapi pertanyaan dari peserta pelatihan. Pernyataan tersebut memiliki total skor sebesar 426 dan modus setuju. Pernyataan yang memiliki skor terendah sebesar 388, yaitu Instruktur dalam menyampaikan materinya sangat mudah dimengerti oleh peserta pelatihan. Artinya, para karyawan merasa instruktur pelatihan sudah baik dalam memberikan penjelasan maupun menanggapi pertanyaan peserta pelatihan.

Pernyataan yang memiliki skor total tertinggi dari variable waktu pelatihan adalah kecukupan waktu pelaksanaan pelatihan (lebih kurang delapan jam) untuk peserta pelatihan memahami materi yang disampaikan. Pernyataan tersebut memiliki total skor sebesar 418 dan modus setuju. Pernyataan yang memiliki skor terendah sebesar 386, yaitu kecukupan waktu pelaksanaan pelatihan untuk instruktur menyampaikan semua materi pelatihan. Artinya, para karyawan merasa waktu pelaksanaan pelatihan sudah sesuai dan efektif.

Pernyataan yang memiliki skor total tertinggi dari variable fasilitas pelatihan adalah alat bantu yang digunakan oleh instruktur dalam menyampaikan materi pelatihan. Pernyataan tersebut memiliki total skor sebesar 385 dan modus setuju. Sebaliknya, pernyataan yang memiliki skor terendah sebesar 345, yaitu kenyamanan ruang belajar yang digunakan pelatihan. Artinya, kenyamanan ruang kerja perlu diperhatikan kembali untuk tercapainya tujuan dari pelatihan.

Pernyataan yang memiliki skor total tertinggi dari variabel motivasi adalah tanggung jawab terhadap pekerjaan yang saya lakukan. Pernyataan tersebut memiliki total skor sebesar 425 dan modus setuju. sedangkan pernyataan yang memiliki skor terendah sebesar 351, yaitu kondisi tempat kerja saya membantu melaksanakan pekerjaan. Secara umum motivasi karyawan mengikuti pelatihan sudah cukup baik.

Pernyataan yang memiliki skor total tertinggi dari variable kinerja adalah pemahaman saya terhadap pekerjaan yang menjadi tanggung jawab saya. Pernyataan tersebut memiliki total skor sebesar 452 dan modus setuju. Pernyataan yang memiliki skor terendah sebesar 419, yaitu tanggung jawab saya terhadap pekerjaan yang saya lakukan. Artinya, kinerja yang baik dari para karyawan merupakan wujud tanggung jawab terhadap perusahaan.

Tabel 1. Karakteristik responden

\begin{tabular}{llcc}
\hline \multicolumn{2}{c}{ Karakteristik responden } & Frekuensi & Persen (\%) \\
\hline Usia & $<30$ tahun & 3 & $2,9 \%$ \\
& $31-40$ tahun & 61 & $58,7 \%$ \\
& $41-50$ tahun & 40 & $38,5 \%$ \\
Lama & $<10$ tahun & 4 & $3,8 \%$ \\
Bekerja & $11-20$ tahun & 62 & $59,6 \%$ \\
& $>20$ tahun & 38 & $36,5 \%$ \\
Pendidikan & SMK & 101 & $97,1 \%$ \\
Terakhir & D2 & 2 & $1,9 \%$ \\
& S1 & 1 & $1 \%$ \\
\hline
\end{tabular}




\section{Hasil Persamaan Struktural (SEM)}

Model struktural dan nilai loading factor dari data yang telah diolah ditampilkan pada Gambar 2 dan Gambar 3.
Berdasarkan Tabel 2, seluruh indikator menunjukkan bahwa model SEM sudah fit atau sudah baik. Data hasil kuesioner sudah mampu menjawab teori yang dibangun.

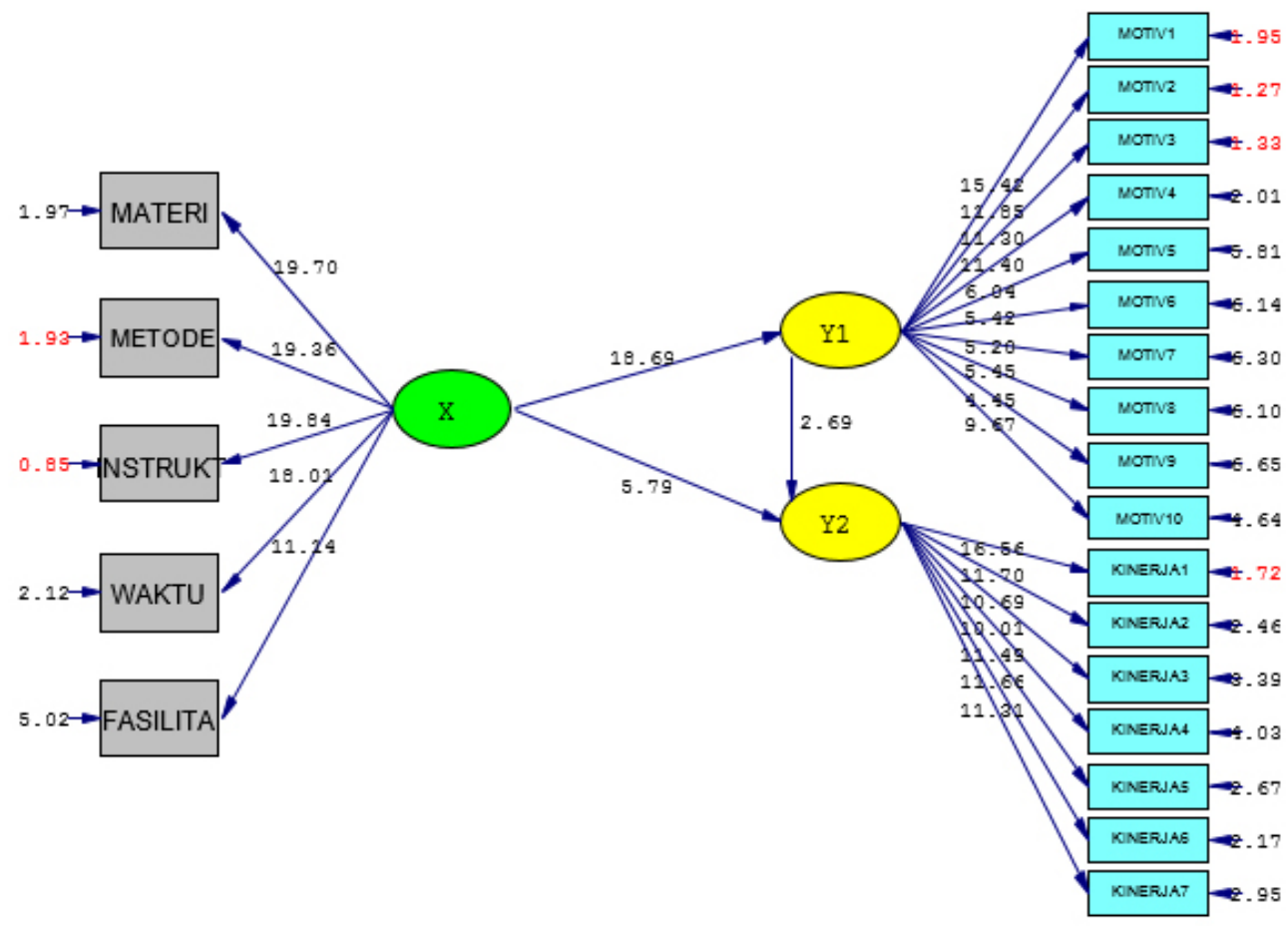

Chi-Square=156.45, df=179, P-value=0.88691, RMSEA=0.000

Gambar 2. T Hitung model SEM

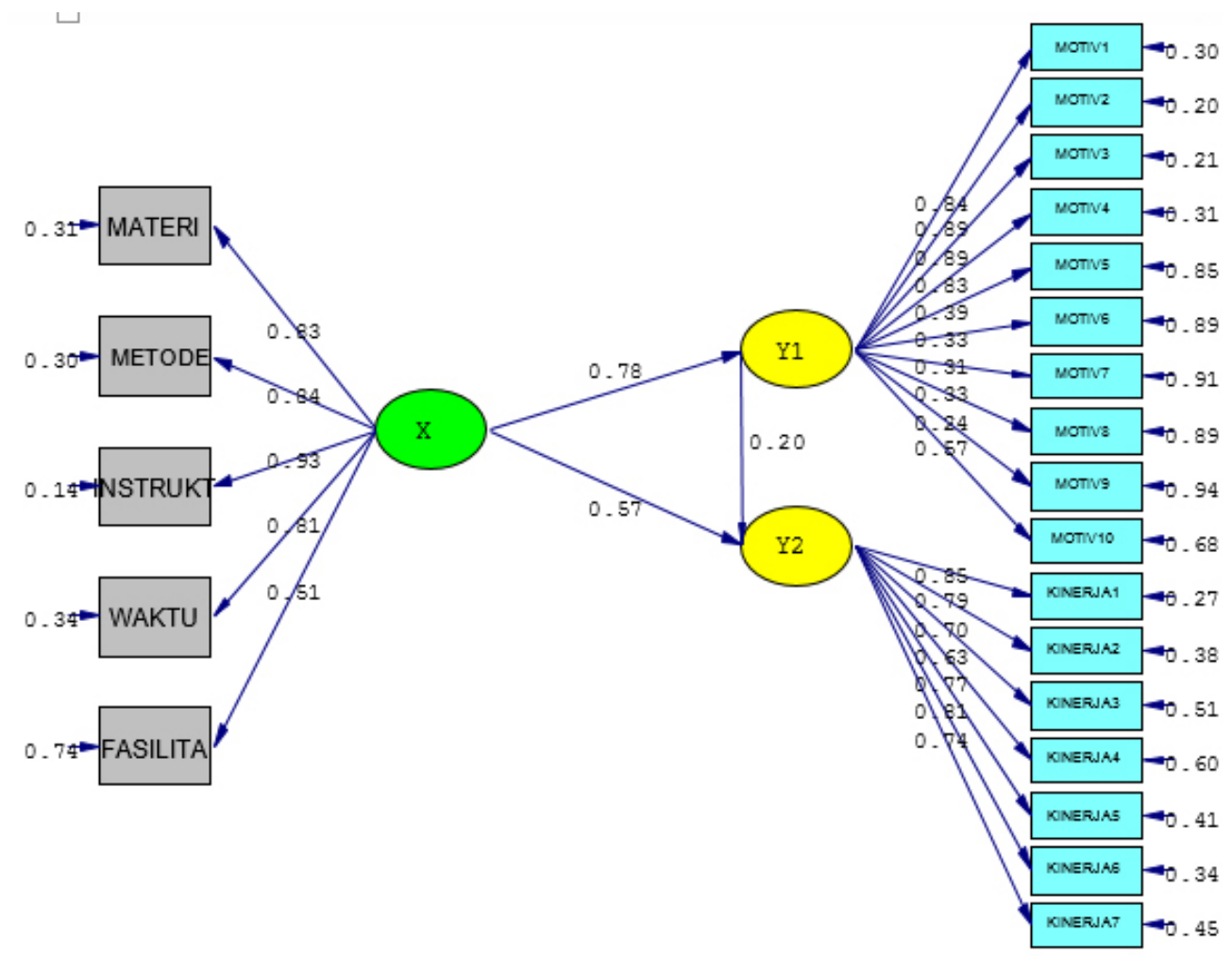

Chi-Square $=156.45, d f=179, P-v a l u e=0.88691$, RMSEA $=0.000$

Gambar 3. Standardized loading factor model SEM 
Tabel 2. Hasil kriteria kesesuaian model SEM

\begin{tabular}{lccc}
\hline \multicolumn{1}{c}{ Goodness-of-Fit } & Cutt-off-Value & Hasil & keterangan \\
\hline RMR (Root Mean Square Residual) & 0,05 atau 0,1 & 0.029 & Good Fit \\
RMSEA(Root Mean square Error of Approximation) & 0,08 & 0.000 & Good Fit \\
GFI (Goodness of fit) & 0,90 & 0.97 & Good Fit \\
AGFI(Adjusted Goodness of fit Index) & 0,90 & 0.96 & Good Fit \\
CFI (Comparative Fit Index) & 0,90 & 1.00 & Good Fit \\
Normed Fit Index (NFI) & 0,90 & 1.00 & Good Fit \\
Non-Normed Fit Index (NNFI) & 0,90 & 0.96 & Good Fit \\
Incremental Fit Index (IFI) & 0,90 & 0.98 & Good Fit \\
Relative Fit Index (RFI) & 0,90 & 0.96 & Good Fit \\
\hline
\end{tabular}

Pengujian hipotesis didasarkan pada nilai yang terdapat pada analisis structural model, tingkat signifikansi path coefficient didapat dari nilai-t dan nilai standardized path coefficient. Batas nilai atau threshold pengujian hipotesis yaitu nilai-t muatan faktornya (loading factor) lebih besar dari nilai kritis $(\geq 1,96)$ dan nilai standardized path coefficient (p) $\geq 0,05$. Rangkuman hasil pengujian hipotesis dapat dilihat pada Tabel 3.

\section{Pelatihan Berpengaruh terhadap Motivasi Kerja}

Hipotesis pertama pengaruh pelatihan (X) terhadap motivasi (Y1). Hasil SEM menunjukkan nilai loading factor sebesar 0,78 dengan nilai mutlak t hitung 18,69. Nilai t hitung lebih besar dari t tabel 1,96 artinya pengaruh pelatihan terhadap motivasi signifikan dan positif, jika persepsi terhadap pelatihan semakin baik maka akan berpengaruh langsung terhadap peningkatan motivasi. Penelitian ini sesuai dengan pendapat MC Gehee (Mangkunegara, 2009) yang menyatakan bahwa pelatih harus mampu memotivasi agar karyawan mampu berprestasi secara maksimal dan menyebarkan respon yang berhubungan dengan serangkaian materi pelatihan. Pelatihan harus ada penguat (reinforcement) guna membangkitkan respon positif dari peserta dan menggunakan konsep pembentukan perilaku (Mangkunegara, 2009). Menurut Wexley dan Yulk (2005) pelatihan dan pengembangan merupakan istilahistilah yang berhubungan denganusaha-usaha berencana yang diselenggarakan untuk mencapai penguasaan skill, pengetahuan dan sikap-sikap karyawan atau anggota organisasi. Hasil penelitian menunjukkan kesesuaian hasil dengan teori yang dibangun bahwa pelatihan yang diberikan kepada karyawan mampu meningkatkan motiasi kerja karyawan. Hasil analisis menunjukkan bahwa pelatihan berpengaruh positif dan signifikan terhadap motivasi kerja. Hal ini membuktikan bahwa semakin baik pelatihan diberikan pada para leader maka motivasi kerja akan semakin tinggi.
Menurut Siagian (1996) manfaat pelatihan diantaranya selain dapat meningkatkan produktivitas kerja juga menciptakan terwujudnya hubungan serasi antara atasan dan bawahan, hal ini dapat meningkatkan motivasi kerja karyawan. Kajian empiris yang turut mendukung penelitian ini dilakukan oleh Khan (2012) bahwa pelatihan mempunyai dampak yang postif terhadap motivasi kerja untuk pencapaian prestasi kerja dalam meningkatkan kinerja karyawan. Penelitian mengenai pengaruh dari variabel pelatihan terhadap motivasi kerja menunjukkan bahwa pelatihan secara positif berpengaruh terhadap motivasi kerja karyawan pada PT. TD Automotive Compressor Indonesia. Pelatihan dapat berpengaruh dalam peningkatan motivasi kerja karyawan, diharapkan manajemen benar-benar memperhatikan pelatihan karyawan. Latar belakang pendidikan karyawan yang berasal dari berbagai macam tingkatan dan bidang membuat skill karyawan berbeda-beda.

\section{Pelatihan Berpengaruh terhadap Kinerja}

Hipotesis kedua pengaruh pelatihan (X) terhadap kinerja (Y2). Hasil SEM menunjukkan nilai loading factor sebesar 0,57 dengan nilai mutlak t hitung 5.79. Nilai t hitung lebih besar dari t tabel 1,96 artinya pengaruh pelatihan terhadap kinerja signifikan dan positif artinya jika persepsi terhadap pelatihan semakin baik maka akan berpengaruh langsung terhadap peningkatan kinerja karyawan. Penelitian mengenai pengaruh dari variabel pelatihan terhadap kerja karyawan, diperoleh hasil variabel pelatihan berpengaruh positif terhadap kinerja kerja karyawan pada PT. TACI. Temuan ini didukung oleh teori dari Hasibuan (2005) yang menyatakan bahwa pelaksanaan program pelatihan membentuk dan meningkatkan kemampuan dan pengetahuan karyawan. Kemampuan dan pengetahuan yang karyawan dapatkan harus mejadikan mereka ahli dalam melakukan tugasnya, 
karena keahlian sifatnya spesifik dan fokus. Sesuai dengan penelitan, pelatihan merupakan suatu rencana usaha untuk memudahkan pembelajaran pekerjaan yang berhubungan dengan pengetahuan, keahlian dan perilaku kerja (Noe, 2011). Pendidikan dan pelatihan dilakukan dengan memberikan materi yang tepat, memiliki latar pendidikan yang baik maka kinerja akan semakin baik (Sukoco, 2010).

Kajian emprik yang turut mendukung hasil peneltian ini adalah seperti yang dikemukakan oleh Sultana et al. (2012) bahwa pelatihan memiliki pengaruh yang signifikan terhadap kinerja karyawan, karena dengan menyelenggarakan program pelatihan secara rutin, maka kinerja karyawan akan meningkat. Pelatihan dapat memperbaiki kinerja, memutakhirkan keahlian karyawan sejalan dengan kemampuan teknologi, mengurangi waktu pembelajaran karyawan agar kompeten dalam pekerjaan, membantu memecahkan masalah operasional, mempersiapkan karyawan untuk promosi, mengorientasikan karyawan terhadap organisasi dan memenuhi kebutuhan pertumbuhan pribadi seperti yang dikatakan oleh Simamora (2004). Hasil penelitian ini juga diperkuat oleh penelitian dari Chukwunenye dan Igboke (2011) yang menyatakan bahwa $49,8 \%$ dari $71,5 \%$ karyawan yang mengikuti pelatihan memiliki kinerja tinggi. Farooq dan Khan (2011) menyatakan bahwa pelatihan berpengaruh signifikan terhadap kinerja staf akademis di Pakistan. Khan et al. (2011) melakukan penelitian yang menyatakan bahwa bahwa pelatihan dan pengembangan memiliki pengaruh yang signifikan terhadap kinerja organisasi. Mulyaningrum (2010) melalui penelitiannya juga menyimpulkan hal yang sama yakni terdapat pengaruh positif antara pelatihan dengan peningkatan kinerja, terbukti denan adanya pelatihan pencapaian target dan produktivitas meningkat.

\section{Motivasi Berpengaruh terhadap Kinerja}

Hipotesis ketiga pengaruh motivasi (Y1) terhadap kinerja (Y2). Hasil SEM menunjukkan nilai loading factor sebesar 0,20 dengan nilai mutlak $\mathrm{t}$ hitung 2,69. Nilai $\mathrm{t}$ hitung lebih besar dari t tabel 1,96 artinya pengaruh motivasi terhadap kinerja signifikan dan positif artinya jika motivasi kerja semakin baik maka akan berpengaruh langsung terhadap peningkatan kinerja karyawan. Motivasi dan kinerja memiliki hubungan yang sangat erat karena motivasi itu sendiri merupakan dorongan bagi individu untuk berprilaku dan melakukan suatu kegiatan atau pekerjaan. Kemampuan melekat dalam diri seseorang serta diwujudkan dalam tindakannya dalam bekerja, sedangkan motivasi adalah aspek yang sangat penting dalam menggerakkan kreativitas dan kemampuan seseorang dalam melakukan pekerjaanya.

Gomes (2000) menyatakan bahwa motivasi sangat diyakini memiliki pengaruh yang besar terhadap kinerja karyawan. Keberhasilan suatu organisasi sangat bergantung pada orang yang bekerja dalam mengelola organisasi tersebut dan kompetensi yang dimilikinya, untuk itulah meningkatkan kinerja karyawan dalam suatu organisasi memerlukan motivasi yang berkesinambungan dan terjaga. Organisasi harus mampu menciptakan kondisi yang kondusif bagi karyawan sehingga motivasi intrinsik dan ekstrinsik karyawan terpenuhi. Hal ini sesuai dengan teori Dua Faktor dari Herzberg mengemukakan bahwa dua faktor yang memengaruhi sikap seseorang terhadap pekerjaannya, yaitu faktor kepuasan (satisfaction) atau disebut juga motivator dan faktor penyebab ketidakpuasan (dissatisfaction) atau disebut juga higiene (Hezberg, 2008).

Kinerja karyawan merupakan hal penting dalam meningkatkan produktivitas karyawan. Untuk meningkatkan kinerja karyawan organisasi harus dapat mengetahui faktor-faktor yang memengaruhi kinerja. Faktor-faktor tersebut diantaranya adalah pelatihan dan motivasi kerja. Kemampuan dan motivasi harus saling mendukung agar memberikan kinerja yang lebih baik (Mangkunegara, 2005). Kamali et al. (2003) menyatakan "that performance directly relates to bality and motivation", dapat diartikan kinerja karyawan langsung berkaitan dengan kemampuan dan motivasi. Noe et al. (2011) berpendapat untuk memecahkan masalah terkait dengan peningkatan kinerja karyawan ada beberapa kemungkinan yang dapat dilakukan oleh organisasi anatar lain melalui pemberian motivasi dan pelatihan kerja.

Tabel 3. Pengujian hipotesis

\begin{tabular}{lccc}
\hline \multicolumn{1}{c}{ Hipotesis } & Standardized & $\mid$ T Hitung $\mid$ & Keterangan \\
\hline Pelatihan $(\mathrm{X}) \rightarrow$ Motivasi (Y1) & 0,78 & 18,69 & Signifikan \\
Pelatihan $(\mathrm{X}) \rightarrow$ Kinerja (Y2) & 0,57 & 5,79 & Signifikan \\
Motivasi $(\mathrm{Y} 1) \rightarrow$ Kinerja (Y2) & 0,20 & 2,69 & Signifikan \\
\hline
\end{tabular}

Keterangan: Jika $\mid t$ hitung $\mid>t$ tabel $(1,96)$ maka significant 
Dapat ditarik kesimpulan bahwa untuk dapat memaksimalkan kinerja karyawan dibutuhkan suatu dorongan untuk memunculkan kemauan dan semangat kerja, yaitu dengan motivasi. Penelitian yang dilakukan oleh Awosusi dan Jegede (2011) menyatakan bahwa ada pengaruh signifikan antara motivasi dengan kinerja. Beberapa penelitian lainnya yang juga menguji hubungan antara motivasi dengan kinerja karyawan, antara lain Cahyono dan Suharto (2005), Rachmawati et al. (2006), Brahmasari (2008), Masrukhin (2006) dan Salleh et al. (2011) yang menyatakan bahwa motivasi kerja berpengaruh positif terhadap kinerja karyawan.

\section{Implikasi Manajerial}

Sumber daya manusia merupakan faktor penting yang dapat mendukung keberhasilan suatu organisasi untuk mencapai tujuan yang hendak dicapai. Maju atau mundurnya suatu organisasi sangat tergantung pada kualitas SDM, salah satu yang dilakukan perusahan dalam meningkatkan motivasi kerja dan juga untuk meningkatkan kinerja karyawan itu sendiri yang ada dalam organisasi tersebut adalah dengan memberikan pelatihan. Seorang leader memiliki tugas dan tanggung jawab khusus untuk bisa melatih dan mengajarkan anggotanya, oleh karena itu, perusahaan memberikan pelatihan kepada karyawan tingkat leader mengenai langkah-langkah dasar untuk mengajar secara efektif dan efisien karena pada dasarnya leader harus mampu mangajarkan anggotanya agar dapat melakukan pekerjaannya.

Untuk meningkatkan kinerja karyawan, ada banyak faktor yang dapat diperhatikan dan terapkan dalam organisasi. Faktor-faktor tersebut antara lain adalah meningkatkan kemampuan karyawan melalui pelatihan dan meningkatkan motivasi karyawan dalam bekerja (motivasi kerja). Pelatihan yang dilakukan harus terencana dengan baik, materi yang isusun harus sesuai dengan kebutuhan, instruktur yang mengajar harus memeliki kompetensi dan dapat memberikan motivasi kepada peserta pelathan sehingga peserta termotivasi dan hasil setelah pelatihan dapat di implementasikan pada pekerjaan sehari-hari. Pelatihan yang dilakukan juga untuk meningkatkan moral dan semangat kerja dan meningkatkan motivasi agar karyawan mampu berprestasi secara maksimal.

Hasil penelitian memberikan bukti yang nyata bahwa pelatihan yang baik akan mampu meningkatkan motivasi kerja dan pengaruh yang positif dan signifikan dalam meningkatkan kinerja karyawan. Berdasarkan hal tersebut maka penting bagi pihak manajerial untuk mengembangkan pelatihan yang lebih baik lagi dalam rangka meningkatkan motivasi kerja karyawan dan kinerja karyawan.

\section{KESIMPULAN DAN SARAN}

\section{Kesimpulan}

Hasil SEM dapat disimpulkan bahwa pelatihan berpengaruh signifikan dan positif terhadap motivasi kerja karyawan. Peningkatan pelatihan terahdap karyawan akan mampu meningkatkan motivasi kerja karyawan. Pelatihan TIJI yang dilakukan perusahaan terhadap leader mampu meningkatkan motivasi karyawan untuk bekerja dengan semangat, menyeleseaikan pekerjaan tepat waktu dan tanggung jawab terhadap pekerjaanya.

Pelatihan berpengaruh signifikan dan positif terhadap kinerja karyawan. Peningkatan pelatihan terahdap karyawan akan mampu meningkatkan kinerja karyawan. Pelatihan TIJI yang dilakukan perusahaan terhadap leader mampu meningkatkan kinerja karyawan untuk menyelesaikan pekerjaan sesuai dengan standar yang ditetapkan, tepat waktu dan dapat memanfaatkan waktu dengan baik.

Motivasi kerja berpengaruh signifikan dan positif terhadap kinerja karyawan. Semakin baik motivasi kerja karyawan akan mampu meningkatkan kinerja karyawan. Motivasi yang timbul setelah melakukan pelatihan TIJI mampu meningkatkan kinerja leader. Leader juga mampu mengajarkan kepada anggotanya mengenai cara kerja yang baik, benar dan aman sehingga menurunkan terjadinya penyimpangan-penyimpangan.

\section{Saran}

Keterbatasan dalam penelitian kali ini adalah terbatas pada karyawan level leader saja dan variable motivasi yang digunakan terbatas pada variabel motivasi seperti yang dikemukakan oleh Hezberg. Untuk kedepannya bisa diteliti lebih lanjut pengaruh pelatihan yang dilakukan terhadap karyawan tingkat manajer dengan teori motivasi yang lainnya. 


\section{DAFTAR PUSTAKA}

Gaikindo. 2015. Domestic Auto Production by Category 2015. http://www.gaikindo.or.id/wp-content/ uploads/2016/01/bycat_prod_jandec15_rev.pdf [4 April 2016].

Mathis RL, Jackson JH. 2003. Human Resource Management. New York: Thompson.

Tabassi AA, Ramli M, Bakar AHA. 2012. Effects of training and motivation practices on teamwork improvement and task efficiency: the case of construction firms. International Journal of Project Management 30(2):213-224.

Nawab S, Bhatti KK, Shafi K. 2011. Effect of motivation on employees performance. Interdisciplinary Journal of Contemporary Research in Business 2(3):1209-1216

Mangkunegara AP. 2005. Sumber Daya Manusia perusahaan. Bandung: Remaja Rosdakarya

Mangkunegara AP. 2009. Evaluasi Kinerja Sumber Daya Manusia. Bandung: Penerbit Refika Aditama

Wexley, Kenneth N, GaryAY. 2005.Perilaku Organisasi dan Psikologi Personalia. Jakarta: Rineka Cipta

Siagian, P Sondang.1996. Manajemen Sumber Daya Manusia. Jakarta: Bumi Aksara.

Khan MI. 2012. The impact of training and motivation on performance of employees. Research Journal of the Institute of Business Administration Karachi Pakistan 7(2):84-95.

Hasibuan, Malayu SP. 2005. Manajemen Sumber Daya Manusia. Jakarta: Bumi Aksara.

Noe RA, John RH, Gerhart, Barry, Patric MW. 2011. Manajemen Sumber Daya Manusia Mencapai Keunggulan Bersaing. Jakarta: Salemba Empat

Sukoco F. 2010. Pengaruh pendidikan dan pelatihan, pembelajaran organisasi terhadap kinerja dengan kompetensi sebagai mediasi. Jurnal Bisnis dan Ekonomi 17(1): 74-84.

Sultana A, Irum S, Ahmed K, Mehmood N. 2012. Impact of training on employee performance : a study of telecomunication sector In Pakistan. Interdisciplinary Journal of Contemporary Research in Business 4(6): 646-661.

Chukwunenye IO, Igboke BN. 2011. Training, manpower development and job performance: Perception and relevance among civil servants in Ebonyi State, Nigeria. Journal of Economics and International Finance 3(6): 399-406.
Farooq M, Aslam K. 2011. Impact oftraining and feedback on employee performance. Journal Pschycologi and Business 5(1):23-33.

Khan G, Khan FA, Aslam M. 2011. Impact of training and development on organizational performance. Journal Business and Management11(7):63-68.

Mulyaningrum. 2010. Pengaruh pelatihan dan kepemimpinan terhadap kinerja karaywan divi marketing AJB Bumiputera 1912 Cabang Kebayoran [tesis]. Jakarta: Universitas Indonesia.

Gomes FC. 2000. Manajemen Sumber Daya Manusia. Yogyakarta: Andi Offset.

Hezberg F, Mausner B, Snyderman BB. 2008. The Motivation to Work. Ed Ke-Sebelas. New York: John Wiley \& Sons, Inc.

Kamali S, Khan B, Khan MB, Khan AB. 2003. Motivation and its impact on job performance. Journal of Economic 2(1): 1-8.

Awosusi OO, Jegede AO. 2011. Motivation and job performances among nurses in the ekiti state environment of Nigeria. Journal Pharmacy and BioSains 2(2):583-595.

Cahyono, Suharto. 2005. Pengaruh budaya organisasi kepemimpinan dan motivasi kerja terhadap kinerja sumber daya manusia di Sekretariat DPRD Provinsi Jawa Tengah. Jurnal Riset Bisnis Indonesia 1(1): 13-30.

Rachmawati, Enny YW, Zaennal H. 2006. Pengaruh motivasi kerja dan gaya kempimpinan terhadap kinerja karyawan pada Badan Kesatuan Bangsa dan Perlindungan Masyarakat Provinsi Jawa Tengah. Jurnal "Dialogue"Ilmu Administrasi dan Kebijakan Politik 3(1): 41-50.

Brahmasari IA. 2008. Pengaruh motivasi kerja, kepemimpinan dan budaya organisasi terhadap kepuasan kerja karyawan serta dampaknya pada kinerja perusahaan (studi kasus pada PT Pei Hai Internasional Wiratama Indonesia). Jurnal Manajemen \& Kewirausahaan 10(2): 124-135.

Masrukhin, Waridin. 2006. Pengaruh motivasi kerja, kepuasan kerja, budaya organisasi dan kepemimpinan terhadap kinerja karyawan. Jurnal Ekonomi dan Bisnis 7(2): 197-209.

Salleh F, Dzulkifli Z, Abdullah WAW, Yaakob NHM. 2011. The effect of motivation on job performance of state government employee in Malaysia. International Journal of Humanities and Social Science 1(4):1-8. 